PART III. OTHER

DZIAŁ III. RÓŻNE

\title{
ASSESSMENT OF VITAMIN D CONTENT IN DIETARY SUPPLEMENTS SOLD IN EU PHARMACIES AND SUPERMARKETS
}

\section{OCENA SUPLEMENTÓW DIETY DOSTĘPNYCH W APTEKACH I SUPERMARKETACH NA TERENIE UE POD KĄTEM ZAWARTOŚCI WITAMINY D}

\author{
Wioletta Agnieszka Żukiewicz-Sobczak ${ }^{1(\mathrm{~A}, \mathrm{D}, \mathrm{E}, \mathrm{G})}$, Klaudia Wołyńczuk $^{1(\mathrm{~B}, \mathrm{C}, \mathrm{F})}$, \\ Paweł Sobczak $^{2(C, D, E, F)}$, Francesco Santoro ${ }^{3(C, D)}$ \\ ${ }^{1}$ Pope John Paul II State School of Higher Education in Biała Podlaska, Poland \\ ${ }^{2}$ Faculty of Production Engineering, Department of Food Engineering and Machines, \\ University of Life Sciences in Lublin, Poland \\ ${ }^{3}$ Department of Agricultural and Environmental Science, University of Bari Aldo Moro, Italy
}

Authors' contribution

Wkład autorów:

A. Study design/planning

zaplanowanie badań

B. Data collection/entry

zebranie danych

C. Data analysis/statistics

dane - analiza i statystyki

D. Data interpretation

interpretacja danych

E. Preparation of manuscript przygotowanie artykułu F. Literature analysis/search wyszukiwanie i analiza literatury G. Funds collection zebranie funduszy

\section{Summary}

One of the main fat-soluble vitamins is vitamin D, whose primary function is the regulation of calcium-phosphate metabolism and mineralization of bone tissue. Vitamin D occurs in two forms: vitamin D2 (ergocalciferol) - found in plants and fungi (mainly yeasts) and vitamin D3 (cholecalciferol) - produced in animals. Hypovitaminosis of vitamin D leads to metabolic bone diseases in children and adults and can also affect the incidence of many chronic diseases such as: multiple sclerosis, diabetes, rheumatoid arthritis, bronchial asthma, cancer, atherosclerosis, coronary artery disease and heart failure. The aim of the current study was to assess the content of vitamin D in dietary supplements available in pharmacies and supermarkets in the EU. The evaluation involved analysing the ratio of vitamin D content in supplements in relation to the typical demand of the organism. This study assessed 15 popular over-the-counter dietary supplements in the form of tablets, capsules, lozenges and lollipops for children as well as in the form of effervescent tablets. On the basis of the labels on the packaging, the vitamin D content of the supplements was assessed in relation to the dietary demands of the body. Self-administration of over-the-counter multivitamin supplements is not an optimal way to increase vitamin D levels. It is recommended, therefore, that individuals requiring vitamin D supplementation seek specialist medical advice to optimal treatment strategies.

Keywords: vitamin D, ergocalciferol, cholecalciferol, vitamins, hypervitaminosis

\section{Streszczenie}

Jedną z głównych witamin rozpuszczalnych w tłuszczach jest witamina D. Kluczową funkcją witaminy D w organizmie człowieka jest regulacja gospodarki wapniowo-fosforanowej oraz mineralizacja tkanki kostnej. Poznane zostały dwie formy witaminy D: witamina D2 (ergokalcyferol) - występująca w roślinach i grzybach (głównie drożdżach) oraz witamina D3 (cholekalcyferol) - wytwarzana w organizmach zwierzęcych. Hipowitaminoza tej witaminy prowadzi do metabolicznych chorób kości u dzieci i dorosłych, a także może mieć wpływ na występowanie wielu chorób przewlekłych takich jak: stwardnienie rozsiane, cukrzyca, reumatoidalne zapalenie stawów, astma oskrzelowa, nowotwory, miażdżyca, choroba wieńcowa, niewydolność serca. Celem pracy była ocena zawartości witaminy D w suplementach diety dostępnych w aptekach oraz supermarketach na terenie UE. Oceniano stosunek zawartości witaminy D w suplementach w odniesieniu do zapotrzebowania organizmu. Materiał badawczy stanowiło 15 popularnych suplementów diety dostępnych bez recepty w aptekach oraz supermarketach na terenie UE. Wykorzystane suplementy były w formie tabletek, kapsułek, tabletek do ssania i lizaków dla dzieci oraz w formie tabletek musujacych. Na podstawie etykiet znajdujących się na opakowaniu oceniano zawartość witaminy D w suplementach w odniesieniu do zapotrzebowania organizmu. Samodzielne dozowanie suplementów diety nie jest optymalnym sposobem na zwiększenie poziomu witaminy D w organizmie. Z tego też względu stosując je należy zasięgać porad specjalisty.

Słowa kluczowe: witamina D, ergokalcyferol, cholekalcyferol, witaminy, hiperwitaminoza
Tables: 3

Figures: 1

References: 14

Submitted: 2019 May 7

Accepted: 2019 Jun 25

Żukiewicz-Sobczak WA, Wołyńczuk K, Sobczak P, Santoro F. Assessment of vitamin D content in dietary supplements sold in EU pharmacies and supermarkets. Health Prob Civil. 2020; 14(1): 43-48. https://doi.org/10.5114/hpc.2019.86267

Address for correspondence / Adres korespondencyjny: Wioletta Agnieszka Żukiewicz-Sobczak, Pope John Paul II State School of Higher Education, Sidorska 95/97, 21-500 Biała Podlaska, Poland, e-mail: wiola.zukiewiczsobczak@gmail.com, phone: +48 833449900

ORCID: Wioletta Agnieszka Żukiewicz-Sobczak https://orcid.org/0000-0002-0142-5102, Paweł Sobczak https://orcid.org/0000-0003-2167-1498,

ORCID: Wioletta Agnieszka Zukiewicz-Sobczak https://orcid.
Francesco Santoro https://orcid.org/0000-0001-9115-8265

Copyright: (C) Pope John Paul II State School of Higher Education in Biała Podlaska, Wioletta Agnieszka Żukiewicz-Sobczak, Klaudia Wołyńczuk, Paweł Sobczak, Francesco Santoro. This is an Open Access journal, all articles are distributed under the terms of the Creative Commons Attribution-NonCommercial-ShareAlike 4.0 International (CC BY-NC-SA 4.0) License (http://creativecommons.org/licenses/by-nc-sa/4.0/), allowing third parties to copy and redistribute the material in any medium or format and to remix, transform, and build upon the material, provided the original work is properly cited and states its license. 


\section{Introduction}

Vitamin D belongs to the group of fat-soluble vitamins and it is essential for healthy physiology. Vitamin D is involved in the regulation of calcium-phosphate metabolism and mineralization of bone tissue [1, 2]. In recent years, other properties of vitamin D have also been observed. It has been found that vitamin D deficiency not only causes metabolic bone diseases in children and adults, it may also increase the risk of many common chronic diseases such as: multiple sclerosis, diabetes, rheumatoid arthritis, bronchial asthma, cancer, atherosclerosis, coronary heart disease, heart failure $[3,4,5]$.

Vitamin D is one of the most commonly deficient. This is due to the fact that few foods naturally contain vitamin $\mathrm{D}$, and only a small number of dietary products is enriched with it. As a consequence, vitamin D deficiency has become an epidemic for all age groups in the United States and Europe [3]. Over the years, a correlation between the geographical latitude, the length of the day and the concentration of vitamin $\mathrm{D}$ in the body has also been observed. This also affects the incidence of disease cases. The prolonged exposure to sunlight enables more effective vitamin D synthesis.

Vitamin D occurs in two forms: vitamin $\mathrm{D}_{2}$ (ergocalciferol) - occurring mainly in plants and fungi (yeasts) and vitamin $\mathrm{D}_{3}$ (cholecalciferol) - synthesized in the body. In the human body both these forms occur and can be supplied with food or produced by exposing the skin to sunlight. Moreover, Provitamin $\mathrm{D}_{3}$, upon exposure to sunlight, is converted to previtamin $\mathrm{D}_{3}$, which, under the influence of heat, undergoes isomerization to vitamin $\mathrm{D}_{3}[1,2]$. A detailed diagram of vitamin $\mathrm{D}$ synthesis is presented in Figure $1[2,6]$.

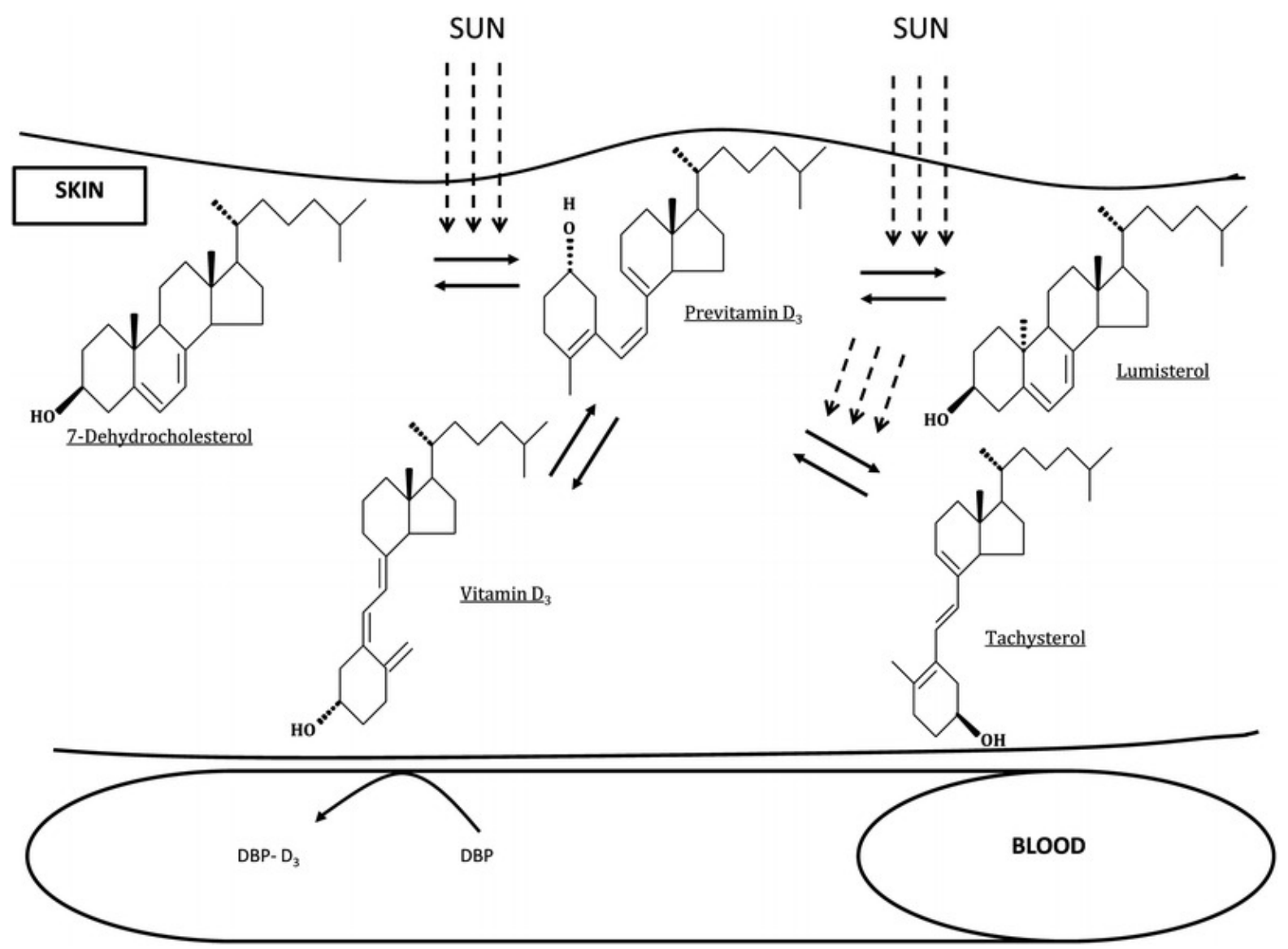

Figure1. Schematic diagram of vitamin $\mathrm{D}_{3}$ synthesis in the skin $[2,6]$

In the first stage of vitamin $\mathrm{D}_{3}$ synthesis, a photolytic conversion of 7-dehydrocholesterol (provitamin D) to cholecalciferol occurs. This process takes approx. 30 minutes and in the majority of vertebrates it occurs under the exposure to sunlight with the participation of appropriate reductase. UVB absorption (within the 290$320 \mathrm{~nm}$ wavelength range) causes the formation of the so-called 7-dehydrocholesterol, which spontaneously undergoes isomerization forming cholecalciferol, i.e. a vitamin D molecule. In this form, vitamin D is transported into the bloodstream. The next metabolic changes, based on the synthesis of biologically active compounds of vitamin $\mathrm{D}_{3}$, are carried out in two stages. Initially, after transporting cholecalciferol with blood to the liver in 
hepatocyte mitochondria, it is hydroxylated by means of 25-hydroxylase. Microsomal fraction enzymes are also involved in this process. The resulting 25-hydroxycholecalciferol - also called calcidiol - is the main form of vitamin D present in the bloodstream, however, it has a relatively low biological activity.

An important place for vitamin D activation in the body is the kidneys. In mitochondria of proximal nephron canals, under the influence of hydroxylase, hydroxylation of calcidiol is observed. The resulting calcitriol $(1 \alpha, 25$ dihydroxycholecalciferol) has about 1000 times higher biological activity than calcidiol. Another form of vitamin D - calcitic acid ( $1 \alpha, 24,25$ dihydroxycholecalciferol) is also present in the body. This compound is highly soluble in water and is therefore easily and quickly removed from the organism. However, it is of little biological significance $[2,6]$.

\section{Physiological demand for vitamin D}

According to the guidelines for Central Europe of 2013 [7], vitamin D supplementation is recommended from the first days of life, regardless of how the child is fed at a dose of: $400 \mathrm{IU} / \mathrm{a}$ day $(10 \mu \mathrm{g} / \mathrm{day}$ ) in relation do daily intake. In the case of children and adolescents, vitamin D supplementation at a dose of 600-1000 IU/a day (15-25 $\mu \mathrm{g} /$ day) is recommended. Both in adults and the elderly after 65 years of age vitamin D supplementation should be between 800 and $2000 \mathrm{IU} / \mathrm{a}$ day, i.e. 20-50 $\mathrm{\mu g} / \mathrm{a}$ day. The dose is adjusted depending on the human body weight and the current season. In the case of obese people, higher doses of vitamin D are recommended [7,8]. According to the Food and Nutrition Institute, the daily requirement of vitamin $\mathrm{D}_{3}$, depending on the age, ranges between 200 and 1000 IU (Table 1) [7, 8].

Table 1. Norms for vitamin D intake [9]

\begin{tabular}{|c|c|c|c|}
\hline Group/gender & Age/years & $\begin{array}{c}\text { Mg of cholecalciferol/ } \\
\text { per person/a day }\end{array}$ & $\begin{array}{c}\text { JM/per person } \\
\text { /a day }\end{array}$ \\
\hline Infants & $0-1$ & 10 & 400 \\
\hline Children & $1-9$ & $15-25$ & $600-1000$ \\
\hline Boys & $10-18$ & $15-25$ & $600-1000$ \\
\hline Girls & $10-18$ & $15-25$ & $600-1000$ \\
\hline Men and women & $19-65$ & $20-50$ & $800-2000$ \\
\hline Persons over 65 years of age & \multicolumn{2}{|c|}{$20-50$} & $800-2000$ \\
\hline
\end{tabular}

Currently, the most accurate indicator of vitamin D levels in the body is the examination of serum levels of calcidiol. People with a blood calcidiol concentration of less than $25 \mathrm{nmol} / \mathrm{l}$ are evidently suffering from vitamin D deficiency. The deficiency is indicated by values of $25-50 \mathrm{nmol} / \mathrm{l}$, while an elevated level (hypervitaminosis) occurs when the concentration of calcidiol is in the range of 50-70 nmol/l. It is much more difficult to determine the limits of physiological norms. At present, a fairly wide range of concentrations, between 70 and $200 \mathrm{nmol} / \mathrm{l}$ of calcidiol in serum, is assumed within the limits of the norm (Table 2). The highest safe value for the organism is considered to be $250 \mathrm{nmol} / \mathrm{l}$. However, so far, no case of vitamin D poisoning has been observed, whereas deficiency, due to its frequent occurrence, is now a serious social problem $[1,9,10]$.

Table 2. Ranges of serum concentrations of calcidiol [1]

\begin{tabular}{|c|c|c|}
\hline \multirow{2}{*}{} & {$[\mathbf{n g} / \mathbf{m l}]$} & Serum concentration of calcidiol \\
\cline { 2 - 3 } & $0-10$ & $0-25$ \\
\hline Deficit & $>10-20$ & $>25-50$ \\
\hline Deficiency & $>20-30$ & $>50-75$ \\
\hline Hypervitaminosis D & $>30-80$ & $75-200$ \\
\hline Recommended concentration & \multicolumn{2}{|c|}{$>100(150)$} \\
Toxic concentration & \multicolumn{2}{|c|}{$>$} \\
\hline
\end{tabular}

\section{Effects of vitamin D deficiency}

Nowadays, vitamin D deficiency is very common and affects $50-80 \%$ of the population. This constitutes a serious epidemiological problem [11]. Long-term vitamin D deficiency causes disturbances in the regulation of calcium-phosphate metabolism as well as in the modelling and mineralization of bones. As a result, children may develop diseases such as rickets, growth disorders, skeletal deformity and an increased risk of bone fractures at 
a later age. In adults, vitamin D deficiency results in osteomalacia and influences the pathogenesis of osteoporosis [2]. Vitamin D deficiency significantly increases the risk of cardiovascular diseases. This is caused, among other things, by the inhibition of the production of rennin (a hormone that affects blood pressure) by means of vitamin D. In addition, too low vitamin D concentration in the body is associated with the occurrence of myocardial infarction, ischemic heart disease and congestive heart failure. It is connected with exerting metabolic effect on the smooth muscle tissue, cardiomyocyte and endometrium of blood vessels through an active form of vitamin D. Low concentrations of 25-hydroxywitamin $\mathrm{D}$ in the body are associated with an increased risk of developing certain cancers (colon, breast, prostate) by about $30-50 \%$, as well as an increased mortality rate as a result of the disease. Vitamin D deficiency increases the risk of multiple sclerosis, type 1 diabetes mellitus and Crohn's disease. Vitamin D receptors are also found in the brain. Therefore, its deficiency can cause the development of psychiatric diseases such as depression and schizophrenia. Some studies have shown that the intake of vitamin D at a concentration of $2000 \mathrm{IU}$ per $\mathrm{kg}$ for three days stimulates the production of catalicidine, which helps to combat viral infections.

\section{Aim of the study}

The aim of the study was to evaluate the content of vitamin D in popular dietary supplements available in pharmacies and supermarkets. The analysed supplements were in the form of capsules, tablets as well as effervescent tablets, lozenges and lollipops for children.

\section{Material and methods}

The study material consisted of 15 popular over-the-counter dietary supplements available in pharmacies and supermarkets in the EU (Table 3). On the basis of manufacturers' labels, vitamin D content in supplements was evaluated in relation to the demand of the body.

Table 3. Vitamin D content in the tested supplements in [ $\mu \mathrm{g}]$ and [IU]

\begin{tabular}{|c|c|c|c|c|c|}
\hline \multicolumn{6}{|c|}{ OVER-THE-COUNTER SUPPLEMENTS } \\
\hline \multirow[b]{2}{*}{ Supplement } & \multicolumn{2}{|c|}{$\begin{array}{c}\text { Vitamin D content per } \\
\text { tablet }\end{array}$} & \multirow[t]{2}{*}{ Form } & \multirow[t]{2}{*}{$\begin{array}{l}\text { Recommended intake } \\
\text { on the packaging }\end{array}$} & \multirow[t]{2}{*}{$\begin{array}{c}\text { RWS (\%) - Reference } \\
\text { intake value for the } \\
\text { average adult }\end{array}$} \\
\hline & [ $\mu \mathrm{g}]$ & [IU] & & & \\
\hline 1 & 50 & 2000 & $\begin{array}{l}\text { Capsule in the form of } \\
\text { vitamin } D_{3}+K_{2}\end{array}$ & 1 capsule per day & $1000 \%$ \\
\hline 2 & 10 & 400 & $\begin{array}{l}\text { Capsule in the form of } \\
\text { vitamin } \mathrm{A}^{+} \mathrm{D}_{3}\end{array}$ & 1-2 capsules per day & $200 \%$ \\
\hline 3 & 1.67 & 66.8 & $\begin{array}{l}\text { Tablet in the form of } \\
\text { multivitamin }\end{array}$ & 1 tablet $3 x$ daily & $16.7 \%$ \\
\hline 4 & 5 & 200 & $\begin{array}{c}\text { Multivitamin in the form } \\
\text { of a tablet for women }\end{array}$ & 1 tablet per day & $100 \%$ \\
\hline 5 & 25 & 1000 & $\begin{array}{l}\text { Capsules for infants, } \\
\text { children and adults }\end{array}$ & $\begin{array}{c}\text { Infants: } 1 \text { capsule per day } \\
\text { Children over } 1 \text { year of } \\
\text { age and adults: } 2 \text { capsules } \\
\text { per day } \\
\end{array}$ & $500 \%$ \\
\hline 6 & 50 & 2000 & $\begin{array}{l}\text { Capsule in the form of } \\
\text { vitamin } D_{3}+K_{2}\end{array}$ & 1 capsule per day & $1000 \%$ \\
\hline 7 & 25 & 1000 & Capsules & 1 capsule per day & $500 \%$ \\
\hline 8 & 100 & 4000 & Capsules for adults & 1 capsule per day & $2000 \%$ \\
\hline 9 & 50 & 2000 & Capsules & 1 capsule per day & $1000 \%$ \\
\hline 10 & 50 & 2000 & Effervescent tablets & 1 tablet per day & $1000 \%$ \\
\hline 11 & 5 & 200 & $\begin{array}{l}\text { Calcium effervescent } \\
\text { tablets + vitamin } D_{3}\end{array}$ & 1 tablet per day & $100 \%$ \\
\hline 12 & 25 & 1000 & Lozenges & 1 tablet per day & $500 \%$ \\
\hline 13 & 25 & 1000 & Lozenges & 2 tablets per day & $500 \%$ \\
\hline 14 & 0.25 & 10 & $\begin{array}{c}\text { Lollipop with vitamins C } \\
\text { and D }\end{array}$ & 1-2 lollipops per day & $50 \%$ \\
\hline 15 & 10 & 400 & $\begin{array}{l}\mathrm{DHA}+\text { vitamin D capsules } \\
\text { for children }\end{array}$ & 1 capsule per day & $100 \%$ \\
\hline
\end{tabular}




\section{Results and discussion}

The studies have shown that vitamin D content in the analysed supplements ranged from 1.67 to 100 [ $\mu \mathrm{g}$ ] (Table 3). Furthermore, only one case of critically low vitamin D content $(1.67 \mu \mathrm{g})$ in the tested supplement (supplement 3) was found. In two dietary supplements, 4 and 10 respectively, the recommended content of vitamin $\mathrm{D}$ for people aged up to 50 years and pregnant/lactating women was reported (Table 1). High content of vitamin D in supplements 2, 5, 7 in the range from 10 to $25 \mu \mathrm{g}$ and extremely high content of vitamin D in supplements 1, 6, 9 and 8 in the range from 50 to $100 \mu \mathrm{g}$ were also observed.

Bjelakovic et al. [12] based on research and observations, suggest that optimal vitamin D status may be associated with fewer cases of cancer and cardiovascular diseases (such as heart attack or stroke). Vitamin D is synthesised in the skin as vitamin $\mathrm{D}_{3}$ (cholecalciferol) or it is obtained from dietary sources or supplements as vitamin $\mathrm{D}_{3}$ or vitamin $\mathrm{D}_{2}$ (ergocalciferol).

It should be noted that among healthy middle-aged adults the target concentration of 25-hydroxywitamin $\mathrm{D}(25(\mathrm{OH}) \mathrm{D})$ is $50 \mathrm{nmol} / \mathrm{L}$ and due to natural intake (exposure to sun and diet) they are sufficient and there is no indication for systematic blood testing or supplementation. However, for middle-aged adults who are ill or weakened, such natural intake is generally insufficient. In this population, the supplementation phase is directed at $25(\mathrm{OH}) \mathrm{D} 75 \mathrm{nmol} / \mathrm{L}$ and the supplementation pattern (200 000 to 400000 IU orally for 2 months). In adults over 65 years of age, the phase of supplement administration should be systematic and ultimately be at $75 \mathrm{nmol} / \mathrm{L}$ (formula $300000 \mathrm{IU}$ orally for 3 months). Regardless of age, the administration phase should be followed by a prolonged maintenance phase of the supplementation to keep the concentration of $25(\mathrm{OH}) \mathrm{D}$ at a constant level [13].

Therefore, it is necessary to differentiate pathological states in the human body and react by adjusting an appropriate dose in a supplementation within a specified period of time. It is worth remembering, however, that this type of treatment has to be consulted with a specialist. According to the studies presented above, on the EU market one can find vitamin D supplements with very different contents. The inappropriate analysis of the labels provided by the manufacturer may lead to pathological conditions related to the poisoning caused by this vitamin. Such incidents may occur particularly often among healthy adults in the spring-summer season, when the diet is rich in bioactive substances and the human body is exposed to sunlight.

\section{Conclusions}

The dietary supplements analysed here contained a broad range of vitamin D concentrations, which satisfy different physiological demands. It should be noted that the use of dietary supplements, without medical consultation, may lead to overdose and cause a number of pathological processes in the body. This is particularly important for children and infants, as the supplements for this group contain a broad spectrum of vitamin D. A well-balanced diet and rational exposure to sunlight are sufficient for a healthy organism. However, it should also be noted that excessive sun exposure at any age and among any occupational group is not recommended for the human body. The main objective of numerous socio-economic programmes is to promote the implementation of safety in a strategic perspective. Sustainability at global level is increasingly attracting the attention of safety, health and environmental (SHE) professionals, however, it is generally limited to issues at management level, while efforts towards achieving sustainable growth should be directed towards balancing social, economic and environmental needs [14].

\section{References:}

1. Napiórkowska L, Franek E. [The role of vitamin D determination in clinical practice]. Choroby Serca i Naczyń. 2009; 6(4): 203-210 (in Polish).

2. Holick MF, MacLaughlin JA, Doppelt SH. Regulation of cutaneous previtamin D3 photosynthesis in man: skin pigment is not an essential regulator. Science. 1981; 211(4482): 590-593.

https://doi.org/10.1126/science.6256855

3. Holick MF. Sunlight and vitamin D for bone health and prevention of autoimmune diseases, cancers and cardiovascular disease. The American Journal of Clinical Nutrition. 2004; 80(6): 1678-1688.

https://doi.org/10.1093/ajcn/80.6.1678s

4. Pludowski P, Holick MF, Grant WB, Konstantynowicz J, Mascarenhas MR, Haq A, et al. Vitamin D supplementation guidelines. Journal of Steroid Biochemistry and Molecular Biology. 2018; 175: 125-135. https://doi.org/10.1016/j.jsbmb.2017.01.021 
5. Hossein-nezhad A, Holick MF. Vitamin D for health: a global perspective. Mayo Clinic Proceedings. 2013; 88(7): 720-755. https://doi.org/10.1016/j.mayocp.2013.05.011

6. Battault S, Whiting SJ, Peltier SL, Sadrin S, Gerber G, Maixent JM. Vitamin D metabolism, functions and needs: from science to health claims. European Journal of Nutrition. 2013; 52(2): 429-441. https://doi.org/10.1007/s00394-012-0430-5

7. Płudowski P, Karczmarewicz E, Chlebna-Sokół D, Czech-Kowalska J, Dębski R, Dobrzańska A, et al. [Vitamin D supplementation in healthy population and risk groups of vitamin D deficiency - practice guidelines for Central Europe 2013]. Standardy Medyczne/Pediatria. 2013; 10: 573-578 (in Polish).

8. Jarosz M, Stoś K, Przygoda B, Matczuk E, Stolińska-Fiedorowicz H, Kłys W. [Vitamins]. In: Jarosz M., editor. [Dietary guidelines for Polish population]. Warszawa: Instytut Żywności i Żwienia; 2017. p. $130-202$ (in Polish).

9. Horst RL, Reinhardt TA, Reddy GS. Vitamin D metabolism. In: Pike JW, Glorieux FH, Feldman D., editors. Vitamin D. 2nd edition. Amsterdam: Academic Press; 2005. p. 15-36.

10. Zdrojewicz Z, Chruszczewska E, Miner M. [The influence of vitamin D on the man organism]. Borgis Medycyna rodzinna. 2015; 2(18): 61-66 (in Polish).

11. Buczkowski K, Chlabicz S, Dytfeld J, Horst-Sikorska W, Jaroszyński A, Kardas P, et al. [Recommendations for vitamin D supplementation]. Forum Medycyny Rodzinnej. 2013; 7(2): 55-58 (in Polish).

12. Bjelakovic G, Gluud LL, Nikolova D, Whitfield K, Wetterslev J, Simonetti RG, et al. Vitamin D supplementation for prevention of mortality in adults. Cochrane Systematic Review. 2011. https://doi.org/10.1002/14651858.cd007470.pub2

13. Annweiler C, Legrand E, Souberbielle JC. Vitamin D in adults: update on testing and supplementation. Geriatr Psychol Neuropsychiatr Vieil. 2018; 16(1): 7-22. https://doi.org/10.1684/pnv.2018.0722

14. Cerruto E, Manetto G, Santoro F, Pascuzzi S. Operator dermal exposure to pesticides in tomato and strawberry greenhouses from hand-held sprayers. Sustainability. 2018; 10(7): 2273. https://doi.org/10.3390/su10072273 